
ISSN : 2615-1995, E-ISSN : 2615-0654

J. Madani., Vol. 3, No. 2, September 2020 (289 - 303)

(C)2018 Lembaga Kajian Demokrasi

dan Pemberdayaan Masyarakat (LKD-PM)

DOI : https://doi.org/10.33753/madani.v3i2.123

\title{
Pengaruh Rasio Profitabilitas, Free Cash Flow, dan Leverage Terhadap Manajemen Laba
}

\author{
Desi Jelanti \\ Fakultas Ekonomi, Universitas Pamulang \\ d_jelanti@yahoo.co.id
}

\begin{abstract}
Abstrak
Penelitian ini bertujuan untuk menguji pengaruh rasio profitabilitas, free cash flow dan leverage terhadap manajemen laba (Studi Empiris Pada Perusahaan Manufaktur Yang Terdaftar di Bursa Efek Indonesia Tahun 2012-2016). Populasi dalam penelitian ini sebanyak 30 perusahaan makanan dan minuman dengan periode pngamatan 2012 sampai 2017. Penelitian ini menggunkan data skunder dan teknik sampel yang dipakai yaitu purposive sampling diperoleh sampel 25 perusahaan makanan dan minuman yang memenuhui kriteria sampel. Model yang digunakan dalam penelitian ini adalah regresi panel menggunakan aplikasi Eviews 8. Metode analisis yang digunakan adalah metode analisis linear berganda untuk menguji menguji pengaruh rasio profitabilitas, free cash flow dan leverage terhadap manajemen laba. Berdasarkan hasil yang diteliti: Rasio Profitabilitas didapat dengan nilai probabilitas sebesar $0.7395>0.05$, dan Free Cash Flow didapat dengan nilai $0.3156>0.05$ berdasarkan hasil tersebut maka $\mathrm{H}_{1}$ ditolak dan $\mathrm{H}_{0}$ diterima maka profitabilitas dan free cah flow tidak berpengaruh terhadap Manajemen Laba. Sedangkan Leverage didapat dengan nilai $0.0003<$ 0.05 maka $\mathrm{H}_{1}$ ditolak dan $\mathrm{H}_{0}$ diterima sehingga Leverage berpengaruh positif signifikan terhadap manajemen laba. Profitabilitas, free cash flow dan leverage diperoleh dengan nilai probabilitas sebesar $0.000000<0.05$ maka secara bersama-sama berpengaruh signifikan terhadap Manajemen Laba.
\end{abstract}

Kata Kunci : Rasio profitabilitas, Free Cash Flow, Leverage, Manajemen Laba

\begin{abstract}
This study aims to examine the effect of profitability ratios, free cash flow, and leverage on management profit and loss (Empirical Study of Manufacturing Companies Listed on the Indonesia Stock Exchange 2012-2016). The population in the study was 30 food companies and with the observation period from 2012 to 2017. The data used in this study were secondary and the sample technique used was purposive sampling, with a sample of 25 food and beverage companies that met the criteria for the sample. The model used in this research is panel regression using the Eviews 8 application. The analytical method used is multiple linear analysis to examine the effect of profitability ratios, free cash flow and leverage on earnings management. Based on the results of the study: Profitability Ratios obtained with a probability value of 0.7395>0.05, and Free Cash Flow obtained with a value of $0.3156>0.05$ based on these results then $H_{1}$ is rejected and $H_{0}$ is accepted then profitability and free flow have no effect on Profit management. While Leverage is obtained with a value of $0.0003<0.05$, then $H_{1}$ is rejected and $H_{0}$ is accepted. Leverage is valued positively significantly towards earnings management. Profitability, free cash flow, and leverage are obtained with a probability value of $0.000000<0.05$, so together they have a significant effect on earnings management.
\end{abstract}

Keywords : Profitability Ratios, Free Cash Flow, Leverage, Profit Management 


\section{PENDAHULUAN}

Di dalam Statement of Financial Accounting Concept (SFAC) Nomor 1, dikatakan bahwa laporan keuangan harus menyajikan informasi yang berguna untuk investor dan calon investor, kreditur dan pengguna lain dalam pengambilan keputusan investasi, kredit, dan keputusan lain yang sejenis, yang rasional. Informasi tersebut harus dapat dipahami oleh mereka yang memiliki wawasan bisnis dan ekonomi supaya informasi yang disajikan dalam laporan keuangan cepat dipahami oleh semua pihak yang berkepentingan dan dapat digunakan untuk pengambilan keputusan, maka penyajian laporan keuangan dalam laporan tahunan harus disertai pengungkapan yang penuh artinya memberikan informasi secara lengkap dan terbuka sehingga tidak menyesatkan orang yang membacanya. Hasil laporan keuangan adalah suatu bentuk pertanggungjawaban yang menyediakan informasi yang bermanfaat untuk setiap penggunan agar mendapatkan hasil keputusan. Sehingga, laporan keuangan yang dibuat dengan mencapai kebutuhan dari setiap pengguna terutama yang berkaitan dengan validitas informasi yang terdapat dalam laporan keuangan. Tetapi pada prakteknya laporan keuangan biasanya disalah gunakan oleh pihak manajemen dengan melancarkan praktik manajemen laba tehadap laporan keuangan tersebut. Salah satu sumber informasi dari pihak eksternal dalam menilai kinerja perusahaan adalah laporan keuangan. Penyampaian informasi melalui laporan keuangaan dilakukan untuk memenuhi kebutuhan pihak-pihak eksternal maupun internal yang kurang memiliki wewenang dalam memperoleh informasi yang mereka butuhkan dari sumber langsung perusahaan (Aryani, 2011). Laporan keuangan adalah objek dalam praktik manajemen laba, sebab mencerminkan kinerja keuangan dalam suatu perusahaan dilihat dalam jangka panjang ataupun jangka pendek. Tuntutan perusahaan untuk mencapai target laba yang ditentukan dapat menjadi motivasi untuk menentukan manajemen laba, alasan lain melakukan manajemen laba adalah adanya harga saham yang dipengauhi oleh laba, resiko, dan spekulasi perusahaan. Pemegang saham (principal) mengharapkan manajemen dapat menjamin kepentingan mereka dan dengan adanya peningkatan laba sebagai indikasi adanya pengambilan modal yang ditanamkan, sementara manajemen menginginkan penilaian kinerja yang baik ditunjukan dengan memperoleh laba yang terus meningkat sehingga dapat meningkatkan insentif manajemen. hal yang bisa dilakukan manajemen untuk mempengaruhi nilai laba perusahaan yang dikelolanya, yaitu melakukan manajemen laba (earnings management). Profitabilitas merupakan salah satu variabel yang sering diteliti kaitannya dengan manajemen laba. Jika perusahaan memiliki Rasio Profitabilitas yang baik, perusahaan mempunyai peluang untuk mempertahankan keberlanjutan usahanya (Solihin, 2009). Fahmi (2011) menyatakan bahwa investor yang berkompeten akan menganalisis dengan cermat kelancaran sebuah perusahaan dan kemampuannya untuk menghasilkan keuntungan Profitabilitas, karena mereka mengharapkan deviden dan harga pasar dari sahamnya. Profitabilitas merupakan rasio untuk menilai efektifitas manajemen secara keseluruhan yang ditunjukkan oleh besar kemapuan keuntungan yang didapat dalam hubungannya dengan hasil pemaskan maupun investasi (Kasmir,2010:80). Rasio yang dipakai untuk mengukur profitabilitas adalah rasio ROE (return on quity). Menurut Prasetya dan Rahardjo (2013) semakin tinggi tingkat profitabilitas perusahaan maka semakin besar manajer perusahaan melakukan praktik manajemen laba. Maka berdasarkan uraian diatas, peneliti tertarik untuk melakukan penelitian dengan judul "Pengaruh Rasio Profitabilitas, Free Cash Flow dan Leverage terhadap manajemen laba pada perusahaan manufaktur yang terdaftar di BEI (2012-2017).

\section{METODE}

\section{Analisis Data dan Pengujian Hipotesis}

Sugiyono (2011:147) analisis data adalah kegiatan setelah data dari seluruh responden terkumpul. Kegiatan dalam analisis data adalah mengelompokkan data berdasarkan variabel dan 
jenis responden, mentabulasi data berdasarkan variabel dari seluruh responden, menyajikan data tiap variabel yang diteliti, melakukan perhitungan untuk menjawab masalah, dan melakukan perhitungan untuk menguji hipotesis yang telah diajukan. Adapun metode analisis data dan pengujian hipotesis yang diperlukan dalam penelitian ini sebagai berikut:

\section{Analisis Statistik Deskriptif}

Statistik deskriptif berfungsi mendeskripsikan objek yang diteliti melalui data sampel atau populasi apa adanya berdasarkan pada nilai minimum, nilai maksimum, mean, dan standar deviasi, dengan tanpa melakukan analisis dan membuat kesimpulan yang berlaku umum dari data tersebut. Pengujian ini dilakukan untuk mempermudah dalam memahami variabel-variabel yang digunakan dalam penelitian. Untuk melihat deskriptif nilai variabel dari beberapa variabel dapat dilihat dari nilai mean, median atau standar deviasinya.

\section{a. Nilai Rata-rata (Mean)}

Mean adalah nilai rata-rata yang didapat dari gabungan kelompok data dibagi dengan banyaknya data. Mean juga merupakan suatu nilai pusat (kesimbangan) untuk suatu variabel, tetapi mean tidak dapat digunakan sebagai ukuran pemusatan untuk jenis data nominal dan ordinal. Simpangan Baku (Standar Deviasi).

\section{Metode Analisis Data}

Metode analisis yang dipakai adalah analisis regresi data panel. Data panel adalah gabungan dari data cross section dan deret waktu (time series) yakni sejumlah variabel diobservasi atas sejumlah kategori dan dikumpulkan dalam suatu jangka waktu tertentu.

\section{Metode Analisis Data Panel}

Metode estimasi model regresi dengan menggunakan data panel dapat dilakukan melalui beberapa pendekatan anatara lain:
a. Metode Common Effect atau Pooled Least
Square (PLS)

Pooled Least Square model adalah metode estimasi model regresi data panel yang paling sederhana dengan asumsi intercept dan koefisien slope yang konstan antar waktu dan cross section (common effect).

Kelemahan Pooled Least Square Model ini adalah dugaan parameter $\beta$ akan biasa karena tidak dapat membedakan observasi yang berbeda pada periode yang sama serta tidak dapat membedakan observasi yang sama pada periode yang berbeda.

b. Metode Fixed Effect Model (FEM)

Teknik model Fixed Effect yaitu teknik mengestimasi data panel dengan menggunakan variabel dummy untuk menangkap adanya perbedaan intersep. Pengertian Fixed Effect ini didasarkan adanya perbedaan intersep antara perusahaan namun intersepnya sama antar waktu (time in variant). Disamping itu, model ini juga mengasumsikan bahwa koefisien regresi (slope) tetap antar perusahaan dan antar waktu. Salah satu cara paling sederhana untuk mengetahui perbedaan adalah dengan mengasusmsikan bahwa intersept adalah berbeda antar perusahaan sedangkan slope-nya tetap sama antar perusahaan.

c. Metode Random Effect Model (REM)

Random effect model merupakan metode estimasi model regresi data panel dengan asumsi koefisien slope dan intercept berbeda antar individu dan antar waktu (random effect). Dimasukkannya variabel dummy di dalam fixed effect model bertujuan untuk mewakili ketidaktahuan tentang model yang sebenarnya. "Namun, ini juga membawa konsekuensi berkurangnya derajat kebebasan (degree of freedom) yang pada akhirnya mengurangi efisiensi parameter. Masalah ini bisa diatasi dengan menggunakan variabel gangguan (error term) yang dikenal dengan metode Random Effect. 


\section{Pemilihan Model Estimasi Data}

Untuk memilih model mana yang paling tepat digunakan untuk pengolahan data panel, maka terdapat beberapa pengujian yang dapat dilakukan, anatara lain:

\section{Uji Chow}

Uji Chow adalah pengujian untuk memilih apakah model digunakan pooled least square model atau fixed effect model.

Uji ini digunakan untuk mengetahui apakah teknik regresi data panel dengan metode fixed effect lebih baik dari regresi model data panel tanpa variabel dummy atau metode common effect.

Langkah-langkah yang dilakukan dalam

Uji Chow-Test adalah sebagai berikut:

1) Estimasi dengan fixed effect.

2) Uji dengan menggunakan Chow-test.

3) Melihat nilai probability F dan chi-square dengan hipotesis:

$\mathrm{H}_{0}$ : Common Effect (CE).

$\mathrm{H}_{1}$ : Fixed Effect (FE).

a) Bila nilai probability $\mathrm{F}$ dan Chisquare $>\alpha=5 \%$, maka uji regresi panel data menggunakan model Common Effect. Dengan kata lain $\mathrm{H}_{0}$ tidak dapat ditolak.

b) Bila nilai probability $\mathrm{F}$ dan Chisquare $<\alpha=5 \%$, maka uji regresi panel data menggunakan model Fixed Effect. Dengan kata lain $\mathrm{H}_{0}$ ditolak.

\section{Uji Hausman}

Hausman test adalah pengujian statistik untuk memilih model mana yang paling tepat digunakan antara fixed effect ataukah random effect. Uji ini dikembangkan oleh Hausman dengan didasarkan pada ide bahwa LSDV di dalam model fixed effect dan GLS adalah efisien sedangkan model OLS adalah tidak efisien, di lain pihak alternatifnya metode OLS efisien dan GLS tidak efisien. Karena itu uji hipotesis nulnya adalah hasil estimasi keduanya tidak berbeda sehingga uji Hausman bisa dilakukan berdasarkan perbedaan estimasi tersebut.

Langkah-langkah yang dilakukan dalam
Hausman-Test adalah sebagai berikut:

1) Estimasi dengan Random Effect.

2) Uji dengan menggunakan HausmanTest.

3) Melihat nilai probability $\mathrm{F}$ dan $\mathrm{Chi}$ square dengan hipotesis :

$\mathrm{H}_{0}$ : Fixed Effect (FE).

$\mathrm{H}_{1}$ : Random Effect (RE).

a) Bila nilai probability $\mathrm{F}$ dan Chisquare $>\alpha=5 \%$, maka uji regresi panel data menggunakan model Random Effect. Dengan kata lain, $\mathrm{H}_{0}$ ditolak.

b) Bila nilai probability $\mathrm{F}$ dan Chisquare $<\alpha=5 \%$, maka uji regresi panel data menggunakan model Fixed Effect Dengan kata lain, $\mathrm{H}_{0}$ tidak dapat ditolak.

\section{Uji Lagrange Multiplier (LM)}

Uji LM dinamakan juga uji signifikansi random effect yang dikembangkan oleh Bruesch-Pagan. Menurut Widarjono (2007: 260) dalam Iqbal (2015 yang diakses Juli 2017), untuk mengetahui apakah model Random Effect lebih baik dari model Common Effect digunakan Lagrange Multiplier (LM). Uji Signifikansi random effect ini dikembangkan oleh Breusch-Pagan. Pengujian didasarkan pada nilai residual dari metode common effect. Uji LM ini didasarkan pada distribusi Chi-Square dengan derajat kebebasan (df) sebesar jumlah variabel independen.

Hipotesis uji langrange multiplier dalam penelitian ini adalah:

$\mathrm{H}_{0}$ : Common Effect Model.

$\mathrm{H}_{1}:$ Random Effect Model.

Dasar penolakan terhadap hipotesis diatas adalah dengan membandingkan nilai Breusch-Pagan dengan $a=0,05$. Perbandingan dipakai apabila hasil Breusch-Pagan lebih besar (>) nilai $\alpha$, maka $\mathrm{H}_{0}$ diterima yang berarti model yang lebih tepat digunakan adalah common effect model. Begitupun sebaliknya, apabila hasil Breusch-Pagan lebih kecil $(<)$ nilai $\alpha$, maka $\mathrm{H}_{0}$ ditolak dan model yang digunakan adalah random effect model. 


\section{Uji Asumsi Klasik}

a. Uji Normalitas Data

Uji ini bertujuan untuk menguji apakah dalam model regresi, variabel independen, variabel dependen atau keduanya memiliki distribusi normal atau tidak. Model Regresi yang baik adalah memiliki distribusi data normal atau mendekati normal (Ghozali, 2012). Proses uji normalitas data dilakukan dengan uji Kolmogorov-Smirnov (K-S)

Uji K-S dilakukan dengan melihat angka probabilitasnya dengan ketentuan:

1. Nilai Signifikan $<0,05$, maka $\mathrm{H}_{0}$ ditolak. Hal ini berarti ada data residual terdistribusi tidak normal.

2. Nilai Signifikan $>0,05$, maka $\mathrm{H}_{0}$ diterima. Hal ini berarti data residual terdistribusi normal

Selain uji K-S, normal tidaknya suatu data dapat dideteksi juga lewat plot grafik histogram, hanya gambar grafik kadang-kadang dapat menyesatkan karena kelihatan distribusinya normal tetapi secara satistik sebenarnya tidak normal (Ghozali, 2012).

Uji normalitas regresi bertujuan untuk menguji apakah dalam model regresi, variabel pengganggu atau residual memiliki distribusi normal. Model regresi yang baik adalah data yang berdistribusi normal atau mendekati normal. Uji normalitas pada penelitian ini menggunakan Eviews. Dalam Eviews, uji normalitas dapat dilakukan dengan uji JerqueBera (JB-test). Untuk mengambil keputusan, fokus pada Jerque-Bera dan Probability.

Dalam Ghozali (2013:165) Uji JB-test adalah uji normalitas untuk sampel besar (asymptotic). Pertama hitung nilai Skewness dan Kurtosis untuk Residual, kemudian lakukan uji JB dengan rumus seperti dibawah ini:

$$
J B=n\left[\frac{S^{2}}{6}+\frac{(k-3)^{2}}{24}\right]
$$

Dimana:

$\mathrm{n}$ = besarnya sampel

$\mathrm{S}=$ koefisien skweness

$\mathrm{K}=$ koefisien Kurtosis.

Nilai JB statitistik mengikuti distribusi
Chi-square dengan 2 df. Nilai JB selanjutnya dapat dihitung signifikansinya untuk menguji hipotesis berikut:

$\mathrm{H}_{0}$ : residual terdistribusi normal

$\mathrm{H}_{\mathrm{a}}$ : residual tidak terdistribusi normal

b. Uji Heterokedastisitas

Uji Heterokedastisitas bertujuan untuk menguji apakah dalam model regresi terjadi ketidaksamaan varians dari residual satu pengamatan ke pengamatan yang lain (Ghozali: 2013). Jika varians dari residual satu pengamatan ke pengamatan lain tetap, maka disebut Homoskedastisitas dan jika berbeda disebut Heterokedastisitas. Model regresi yang baik adalah yang Homoskedastisitas atau tidak terjadi Heterokedastisitas (Ghozali, 2013).

Salah satu asumsi dalam regresi berganda adalah distribusi residual/error sama (homoskedastisitas) dan independen atau tidak saling berhubungan dengan residual pengamatan lain dalam model. Asumsi ini didukung oleh nilai rata-rata error adalah 0 , dan keragaman yang konstan. Ketika eror tidak memiliki keragaman yang konstan maka persamaan mengandung masalah heterokedastisitas atau:

$$
\operatorname{Var}\left(\mathrm{e}_{\mathrm{t}}\right)=\sigma_{t}^{2} \text { (heterokedastisitas) }
$$

Asumsi homoskesatisitas diberikan oleh persamaan berikut:

$$
\operatorname{Var}\left(\mathrm{e} \mid \mathrm{X}_{1}, \mathrm{X}_{2}, \ldots ., \mathrm{Xn}\right)=\boldsymbol{\sigma} \mathbf{2}
$$

Pada penerapannya error sulit memiliki keragaman yang konstan, hal ini sering terjadi pada data silang (cross section) dibanding data runtun waktu (time series).

Menurut Ghozali dan Ratmono (2013), ada dua cara untuk mendeteksi ada tidaknya heterokedastisitas, yaitu, metode grafik dan metode uji statistik (uji formal). Metode grafik relatif lebih mudah dilakukan namun memiliki kelemahan yang cukup signifikan karena jumlah pengamatan mempengaruhi tampilannya. Semakin sedikit jumlah pengamatan semakin sulit menginterprestasikan hasil grafik plots. Selain itu, interprestasi setiap orang dengan melihat po- 
la grafik bisa berbeda-beda. Oleh sebab itu, diperlukan uji statistik formal yang lebih dapat menjamin keakuratan hasil.

Ada beberapa uji statistik yang dapat digunakan untuk mendeteksi ada tidaknya heterokedastisitas, antara lain: 1) uji glejser, 2) uji white, 3) uji Breusch-Pagan-Godfrey, 4) uji Harvey, dan 5) uji Park. Glejser mengusulkan untuk meregres nilai absolute residual (AbsUi) terhadap variabel independen lainnya dengan persamaan regresi sebagai berikut:

$$
|\mathbf{U i}|=\mathbf{a}+\boldsymbol{\beta} \mathbf{X i}+\mathbf{u i}
$$

Jika koefisien variabel independen $\mathrm{Xi}$ (yaitu $\beta$ ) signifikan secara statistik, yakni $\leq$ 0,05 maka mengindikasikan terdapat heterokedastisitas dalam model. Dan sebaliknya, jika nilai signifikansinya lebih besar dari 0,05 untuk masing-masing variabel independen, maka tidak terjadi masalah heterokedastisitas.

c. Uji Multikolinearitas

Uji Multikolinearitas bertujuan untuk menguji apakah model regesi ditemukan adanya korelasi antar variabel bebas atau independen (Ghozali,2012). Untuk menguji Multikolinearitas, amak dapat dilakukan dengan pengujian dengan menggunakan uji Variance inflation Factor (VIP) dengan ketentuan sebagai berikut:

1. Mempunyai angka Tolerance mendekati $>0,10$.

2. Apabila memiliki nilai VIP (Variance Inflation Factor) $<10$.

3. Jika kedua kriteria diatas terpenuhi, maka bisa disimpulkan bahwa variabelvariabel independen tidak memiliki masalah Multikolinearitas. Model regresi yang baik seharusnya tidak terjadi korelasi antara variabel independen (Ghozali, 2012).

d. Uji Autokorelasi

Uji ini diperuntukan untuk menguji apakah dalam model regresi linear ada korelasi anatra kesalahan pengganggu (residual) pada periode $t$ dengan kesalahan pengganggu pada periode t-1 (sebelumnya). Gejala ini menimbulkan konsekunsi yaitu interval keyakinan menjadi lebih lebar serta varians dan kesalahan standar akan ditafsir terlalu rendah. Uji autokorelasi dilakukan dengan Run test untuk menguji apakah antar residual terdapat korelasi yang tinggi.

Cara mendeteksi autokorelasi dapat dideteksi dengan menggunakan berbagai jenis analisis, yaitu antara lain: Uji Durbin Watson, Uji Breucsh Godfrey, Uji Durbin Watson h, The Engle's ARCH test.

Model regresi yang baik adalah regresi yang bebas dari autokorelasi. Untuk menguji autokorelasi penelitian ini menggunakan uji autokorelasi dengan uji Durbin-Watson hanya digunakan untuk autokoelasi satu (first order autocorrelation) dan mensyaratkan adanya interpect (konstanta) dalam model regresi dan tidak ada variabel lagi dalam variabel bebas (Ghazali 2014:90). Uji DurbinWatson akan menghasilkan nilai DurbinWatson yang nantinya akan dibandingkan dengan dua nilai Durbin-Watson Tabel dan Durbin Upper (DU). Dikatakan tidak terdapat autokorelasi jika nilai DW $>$ DU atau $(4$ - DW) > DU.

\section{Pengujian Hipotesis}

a. Analisis Korelasi Suatu Model Regresi (Goodness of Fit)

Ketepatan fungsi regresi sampel dalam menaksir nilai aktual dapat diukur dari goodness of fit. Secara statitik dapat diukur dari nilai koefisien determinasi, nilai statistik F dan nilai statistik t. Perhitungan statistik disebut signifikan secara statistik apabila nilai uji statistiknya berada dalam daerah kritis (daerah di mana $\mathrm{H}_{0}$ ditolak). Sebaliknya disebut tidak signifikan bila nilai uji statistiknya berada dalam daerah dimana $\mathrm{H}_{0}$ tidak dapat ditolak. (Ghozali, 2013).

b. Korelasi Ganda (Uji Statistik F)

Uji statistik F pada dasarnya menunjukkan apakah semua variabel independen yang dimasukkan dalam model mempunyai pengaruh secara bersama-sama atau simultan terhadap variabel dependen. Hipotesis nol adalah joint hypothesis bahwa $\beta_{1}, \beta_{2} \ldots . . . \mathrm{k}$ secara simultan sama dengan nol. (Ghozali, 
2013:61).

$\mathrm{H}_{0}: \beta_{1}=\beta_{2}=\ldots \ldots \ldots . . . \mathrm{k}=0$

Pengujian hipotesis ini sering disebut pengujian signifikansi keseluruhan (overall significance) terhadap garis regresi yang ingin menguji apakah (Y) fraud secara linier berhubungan dengan kedua $\left(\mathrm{X}_{1}\right)$ asimetri informasi dan $\left(\mathrm{X}_{2}\right)$ financial stability. Joint hypothesis dapat diuji dengan teknik analisis variance ANOVA (Ghozali, 2013:61).

\section{HASIL dan PEMBAHASAAN}

\section{Hasil}

Kesimpulan dari uji pemilihan model seperti yang dijabarkan model analisis regresi yang paling cocok untuk penelitian ini adalah Random Effect Model. Berdasarkan nilai yang diperoleh nilai $\mathrm{F}_{\text {hitung }}>\mathrm{f}_{\text {tabel }}(4.642881>2.43)$ dan signifikasi 0.05 probabilitas sebesar 0.000000 . Oleh karena probabilitas jauh lebih kecil dari 0.05 , maka dapat disimpulkan bahwa koefisien regresi rasio profitabilitas, free cash flow dan leverage dengan kata lain $\mathrm{H}_{1}$ diterima dan menolak $\mathrm{H}_{0}$. Kesimpulan hasil output-nya adalah ketiga variabel independen secara bersama-sama berpengaruh positif terhadap manajemen laba.

\section{Pembahasan}

Berdasarkan pengolahan data melalui software Eviews 8, diperoleh nilai minimum, maksimum, rata-rata, dan standar deviasi dari masing-masing variabel penelitian. Hal tersebut dapat dilihat pada tabel berikut:

\begin{tabular}{|c|c|c|c|c|}
\hline \multicolumn{5}{|c}{ Tabel 1. Statistik Deskriptif } \\
\hline & MAN_LABA & PROFIT & FCF & LEV \\
\hline Mean & 0.384100 & 34.29987 & 0.584682 & 0.992325 \\
\hline Median & 0.392252 & 20.77367 & 0.611519 & 0.950854 \\
\hline Maximum & 2.029544 & 247.3863 & 2.419943 & 3.395605 \\
\hline Minimum & 0.006701 & -111.5639 & -2.983871 & -0.369239 \\
\hline Std. Dev. & 0.257044 & 49.86771 & 0.564780 & 0.513870 \\
\hline Skewness & 2.522408 & 2.010823 & -1.330693 & 0.729924 \\
\hline Kurtosis & 15.88843 & 9.123197 & 13.21418 & 5.571384 \\
\hline & & & & \\
\hline Jarque-Bera & 1197.262 & 335.4198 & 696.3284 & 54.64481 \\
\hline Probability & 0.000000 & 0.000000 & 0.000000 & 0.000000 \\
\hline & & & & \\
\hline Sum & 57.61503 & 5144.981 & 87.70237 & 148.8488 \\
\hline Sum Sq. Dev. & 9.844645 & 370531.5 & 47.52746 & 39.34532 \\
\hline
\end{tabular}

\begin{tabular}{|c|c|c|c|c|}
\hline Observations & 150 & 150 & 150 & 150 \\
\hline \multicolumn{6}{|c|}{ Sumber: Data Diolah Penulis menggunakan e-views 8, 2018} \\
\hline
\end{tabular}

Berdasarkan hasil uji analisis statistik deskriptif pada tabel di atas, menunjukkan bahwa banyak jumlah sampel penelitian (observations) yaitu sebesar 150 perusahaan. Jumlah tersebut merupakan total sampel perusahaan manufaktur subsektor makanan dan minuman selama 6 tahun selama pendekatan pada penelitian dari tahun 2012 sampai dengan 2017 dimana setiap tahunnya terdapat 25 perusahaan manufaktur yang menjadi sampel penelitian.

Dari total pengamatan variabel profitabilitas $\left(\mathrm{X}_{1}\right)$ memiliki nilai rata-rata mean sebesar, 34.29987 nilai median sebesar 20.77367 , nilai maksimum sebesar 247.3863, nilai minimum sebesar -111.5639, nilai standar deviasi sebesar 49.86771, nilai skwness sebesar 2.010823, nilai kurtosis sebesar 9.123197, Jarque-Bare memiliki nilai 1197.262, nilai probablility sebesar 0.000000 , nilai sum sebesar 5144.981, dan niai sum q. Dev sebesar 370531.5.

Variabel Free Cash Flow $\left(\mathrm{X}_{2}\right)$ memiliki nilai mean sebesar, 0.584682, nilai median sebesar 0.611519 , nilai maksimum sebesar, 2.419943 nilai minimum sebesar, -2.983871 nilai standar deviasi sebesar 0.564780, nilai skwness sebesar -1.330693, nilai kurtosis sebesar 13.21481, Jarque-Bare memiliki nilai 696.3284, nilai probablility sebesar 0.000000 , nilai sum sebesar 73.99300 , dan nilai sum q. Dev sebesar 47.52746.

Variabel Leverage $\left(\mathrm{X}_{3}\right)$ memiliki nilai mean sebesar, 0.992325 nilai median sebesar 0.950854, nilai maksimum sebesar 0.006701 , nilai minimum sebesar 3.395605, nilai standar deviasi sebesar -0.369239 , nilai skwness sebesar 0.153870 , nilai kurtosis sebesar 5.571384, Jarque-Bare memiliki nilai 54.64481, nilai probablility sebesar 0.000000 , nilai sum sebesar 148.8488 , dan niai sum q. Dev sebesar 39.34532 .

Variabel Manajemen Laba (Y) memiliki nilai mean sebesar, 0.384100 , nilai median sebesar 0.392252 , nilai maksimum sebesar 2.029544, nilai minimum sebesar 0.006701 , nilai standar deviasi sebesar 0.257044, nilai skwness sebesar 2.522408, nilai kurtosis sebesar, 15.88843 Jarque-Bare 
memiliki nilai 1197.262, nilai probablitity sebesar 0.000000 , nilai sum sebesar 57.61503, dan nilai sum q. Dev sebesar 9.844645 .

\section{Pemilihan Model Estimasi}

Didalam menganalisis data panel, terdapat tiga model regresi berganda yang perlu dipilih yang paling cocok dengan data yang diteliti, yaitu Common Effect Model, Fixed Effect Model, dan Random Effect Model. Pertama-tama penulis melakukan uji chow, untuk memilih antara Common Effect Model dengan Fixed Effect Model mana yang lebih sesuai dijadikan model penelitian

a. Uji F Restricted (Uji Chow)

\begin{tabular}{|c|c|c|c|c|}
\hline \multicolumn{5}{|c|}{ Tabel 2. Hasil Uji Chow } \\
\hline \multicolumn{5}{|c|}{$\begin{array}{l}\text { Redundant Fixed Effects Tests } \\
\text { Equation: Untitled } \\
\text { Test cross-section fixed effects }\end{array}$} \\
\hline \multicolumn{2}{|c|}{ Effects Test } & Statistic & d.f. & Prob. \\
\hline \multicolumn{2}{|c|}{ Cross-section F } & 4.471940 & $(24,122)$ & 0.0000 \\
\hline \multicolumn{2}{|c|}{ Cross-section Chi-square } & 94.668895 & 24 & 0.0000 \\
\hline \multicolumn{5}{|c|}{$\begin{array}{l}\text { Cross-section fixed effects test equation: } \\
\text { Dependent Variable: MAN_LABA } \\
\text { Method: Panel Least Squares } \\
\text { Date: } 10 / 13 / 18 \text { Time: } 22: 22 \\
\text { Sample: } 20122017 \\
\text { Periods included: } 6 \\
\text { Cross-sections included: } 25 \\
\text { Total panel (balanced) observations: } 150\end{array}$} \\
\hline Variable & Coefficient & Std. Error & t-Statistic & Prob. \\
\hline C & 0.206228 & 0.067645 & 3.048653 & 0.0027 \\
\hline PROFIT & -0.000303 & 0.000407 & -0.745913 & 0.4569 \\
\hline FCF & 0.031157 & 0.042287 & 0.736793 & 0.4624 \\
\hline LEV & 0.171380 & 0.046469 & 3.688008 & 0.0003 \\
\hline \multicolumn{2}{|l|}{ R-squared } & 0.103821 & $\begin{array}{l}\text { Mean } \\
\text { dependent } \\
\text { var }\end{array}$ & 0.384100 \\
\hline \multicolumn{2}{|c|}{ Adjusted R-squared } & 0.085406 & $\begin{array}{l}\text { S.D. } \\
\text { dependent } \\
\text { var }\end{array}$ & 0.257044 \\
\hline \multicolumn{2}{|c|}{ S.E. of regression } & 0.245822 & $\begin{array}{l}\text { Akaike info } \\
\text { criterion }\end{array}$ & 0.057888 \\
\hline \multicolumn{2}{|c|}{ Sum squared resid } & 8.822566 & $\begin{array}{l}\text { Schwarz } \\
\text { criterion }\end{array}$ & 0.138171 \\
\hline \multicolumn{2}{|l|}{ Log likelihood } & -0.341589 & $\begin{array}{l}\text { Hannan- } \\
\text { Quinn criter. }\end{array}$ & 0.090505 \\
\hline \multicolumn{2}{|l|}{ F-statistic } & 5.637951 & $\begin{array}{l}\text { Durbin- } \\
\text { Watson stat }\end{array}$ & 0.827715 \\
\hline \multicolumn{2}{|c|}{ Prob(F-statistic) } & 0.001103 & & \\
\hline
\end{tabular}

Berdasarkan uji chow pada tabel di atas dapat diketahui probabilitas crosssection chi-square menunjukkan nilai sebesar 0,0000, nilai tersebut kurang dari a $(0,05)$ maka dapat disimpulkan hasil dari uji chow memilih Fixed Effect Model. Selanjutnya saat Fixed Effect Model yang terpilih, penulis melakukan uji hausman untuk menguji antara Fixed Effect Model dengan Random Effect Model mana yang lebih tepat untuk dijadikan model penelitian.

b. Uji Hausman

\begin{tabular}{|c|c|c|c|c|}
\hline & & Uji Haus & & \\
\hline $\begin{array}{l}\text { Correlated R } \\
\text { Equation: Un } \\
\text { Test cross-se }\end{array}$ & $\begin{array}{l}\text { m Effects - H } \\
\text { random effe }\end{array}$ & man Test & & \\
\hline Test & mary & $\begin{array}{l}\text { Chi-Sq. } \\
\text { Statistic }\end{array}$ & Chi-Sq. d.f. & Prob. \\
\hline Cross-se & random & 0.673045 & 3 & 0.8795 \\
\hline Cross-sectio & dom effects & comparison & & \\
\hline Variable & Fixed & Random & Var(Diff.) & Prob. \\
\hline PROFIT & -0.000074 & -0.000132 & 0.000000 & 0.7026 \\
\hline FCF & 0.055766 & 0.043510 & 0.000571 & 0.6081 \\
\hline LEV & 0.148893 & 0.158919 & 0.000311 & 0.5694 \\
\hline $\begin{array}{l}\text { Cross-sectior } \\
\text { Dependent } \\
\text { Method: Pan } \\
\text { Date: } 10 / 13 / 1 \\
\text { Sample: } 2012 \\
\text { Periods inclu } \\
\text { Cross-sectior } \\
\text { Total panel lb }\end{array}$ & $\begin{array}{l}\text { dom effects } \\
\text { le: MAN_LAE } \\
\text { ast Squares } \\
\text { ime: } 22: 25 \\
7 \\
6 \\
\text { cluded: } 25 \\
\text { ced) observa }\end{array}$ & $\begin{array}{l}\text { equation: } \\
: 150\end{array}$ & & \\
\hline Variable & Coefficient & Std. Error & t-Statistic & Prob. \\
\hline C & 0.206287 & 0.060528 & 3.408142 & 0.0009 \\
\hline PROFIT & $-7.41 \mathrm{E}-05$ & 0.000426 & -0.173976 & 0.8622 \\
\hline FCF & 0.055766 & 0.049377 & 1.129382 & 0.2610 \\
\hline LEV & 0.148893 & 0.046827 & 3.179635 & 0.0019 \\
\hline & & Is Specificat & & \\
\hline & Cross-sec & fixed (dumn & variables) & \\
\hline R-squared & & 0.523239 & $\begin{array}{l}\text { Mean } \\
\text { dependent } \\
\text { var }\end{array}$ & 0.384100 \\
\hline Adjusted R-s & & 0.417727 & $\begin{array}{l}\text { S.D. } \\
\text { dependent } \\
\text { var }\end{array}$ & 0.257044 \\
\hline S.E. of regres & & 0.196142 & $\begin{array}{l}\text { Akaike info } \\
\text { criterion }\end{array}$ & -0.253238 \\
\hline Sum squared & & 4.693539 & $\begin{array}{l}\text { Schwarz } \\
\text { criterion }\end{array}$ & 0.308747 \\
\hline Log likelihooc & & 46.99286 & $\begin{array}{l}\text { Hannan- } \\
\text { Quinn criter. }\end{array}$ & -0.024921 \\
\hline F-statistic & & 4.959024 & $\begin{array}{l}\text { Durbin- } \\
\text { Watson stat }\end{array}$ & 1.522981 \\
\hline Prob(F-statis & & 0.000000 & & \\
\hline
\end{tabular}

Dari tabel di atas dapat diketahui nilai probabilitas cross-section random 0.8795 , nilai tersebut lebih besar dari a $(0,05)$ maka dapat disimpulkan hasil dari uji hausman memilih Random Effect 
Model. Selanjutnya saat Random Effect Model yang terpilih, penulis melakukan uji lagrange multiplier untuk menguji antara Common Effect Model dengan Random Effect Model mana yang lebih tepat dipakai untuk penelitian ini.

c. Uji Langrange Multiplier

\begin{tabular}{|c|c|c|c|}
\hline \multicolumn{4}{|c|}{ Tabel 4. Uji Lagrange Multiplier } \\
\hline \multicolumn{4}{|c|}{$\begin{array}{l}\text { Lagrange multiplier (LM) test for panel data } \\
\text { Date: } 10 / 13 / 18 \text { Time: } 22: 10 \\
\text { Sample: } 20122017 \\
\text { Total panel observations: } 150 \\
\text { Probability in () }\end{array}$} \\
\hline $\begin{array}{l}\text { Null (no rand. effect) } \\
\text { Alternative }\end{array}$ & $\begin{array}{l}\text { Cross- } \\
\text { section } \\
\text { One-sided }\end{array}$ & $\begin{array}{c}\text { Period } \\
\text { One-sided }\end{array}$ & Both \\
\hline \multirow{2}{*}{ Breusch-Pagan } & 47.65382 & 0.673893 & 48.32771 \\
\hline & $(0.0000)$ & $(0.4117)$ & $(0.0000)$ \\
\hline \multirow{2}{*}{ Honda } & 6.903174 & 0.820910 & 5.461752 \\
\hline & $(0.0000)$ & $(0.2058)$ & $(0.0000)$ \\
\hline \multirow{2}{*}{ King-Wu } & 6.903174 & 0.820910 & 3.613183 \\
\hline & $(0.0000)$ & (0.2058) & (0.0002) \\
\hline \multirow[t]{2}{*}{ GHM } & -- & -- & 48.32771 \\
\hline & -- & -- & $(0.0000)$ \\
\hline
\end{tabular}

Dari tabel di atas dapat diketahui nilai Breusch-Pagan 0,0000, nilai tersebut lebih kecil dari a $(0,05)$ maka dapat disimpulkan hasil dari uji Lagrange Multiplier memilih Random Effect Model. Kesimpulan atas uji pemilihan model dapat dilihat dalam tabel 4.

d. Kesimpulan Pemilihan Model Estimasi

\begin{tabular}{l}
\hline \multicolumn{3}{c|}{ Tabel 5. Kesimpulan Uji Pemilihan Model } \\
\begin{tabular}{|c|c|c|}
\hline Jenis Uji & Perbandingan Model & Model Terpilih \\
\hline Uji Chow & CEM vs FEM & FEM \\
\hline Uji Hausman & REM vs FEM & REM \\
\hline Uji Lagrange Multiplier & CEM vs REM & REM \\
\hline \multicolumn{3}{|c|}{ Sumber: Diolah penulis } \\
\hline
\end{tabular}
\end{tabular}

Kesimpulan dari uji pemilihan model seperti yang dijabarkan pada tabel 5 , model analisis regresi yang paling cocok untuk penelitian ini adalah Random Effect Model.

\section{Uji Asumsi Klasik}

a. Uji Normalitas

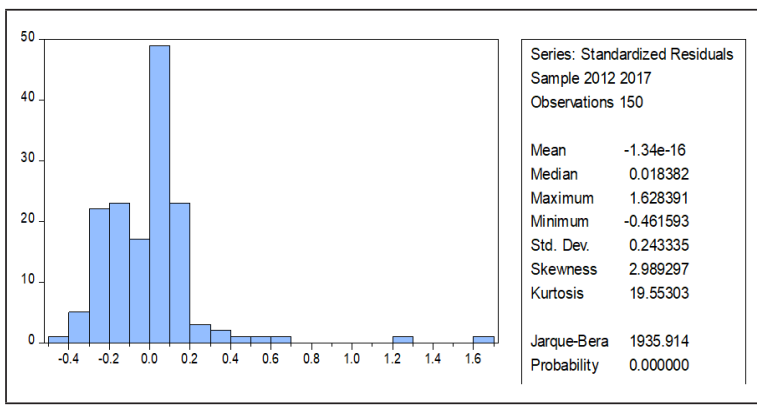

Gambar 1. Kurva Histogram

Sumber : Data Diolah Penulis, 2018

Dilihat dari gambar grafik diatas terlihat bahwa nilai probability 0.000000 dari hasil tersebut dapat diartikan lebih kecil dari nilai signifikan yaitu 0.05 yang berarti bahwa data residul berdistribusi tidak normal.

b. Uji Heterokedastisitas

\begin{tabular}{|c|c|c|c|c|}
\hline \multicolumn{5}{|c|}{ Tabel 6. Uji Heterokedastisitas } \\
\hline \multicolumn{5}{|c|}{ Heteroskedasticity Test: White } \\
\hline F-statistic & 0.211429 & \multicolumn{2}{|c|}{ Prob. $F(9,140)$} & 0.9924 \\
\hline $\begin{array}{l}\text { Obs*R- } \\
\text { squared }\end{array}$ & 2.011440 & \multicolumn{2}{|c|}{ Prob. Chi-Square(9) } & 0.9913 \\
\hline $\begin{array}{l}\text { Scaled } \\
\text { explained SS }\end{array}$ & 17.67727 & \multicolumn{2}{|c|}{ Prob. Chi-Square(9) } & 0.0391 \\
\hline \multicolumn{5}{|c|}{$\begin{array}{l}\text { Test Equation: } \\
\text { Dependent Variable: RESID^2 } \\
\text { Method: Least Squares } \\
\text { Date: } 10 / 13 / 18 \text { Time: } 22: 37 \\
\text { Sample: } 1150 \\
\text { Included observations: } 150\end{array}$} \\
\hline Variable & Coefficient & Std. Error & t-Statistic & Prob. \\
\hline C & -0.061730 & 0.236108 & -0.261447 & 0.7941 \\
\hline $\mathrm{PROFIT}^{\wedge} 2$ & $-2.18 \mathrm{E}-06$ & 4.73E-06 & -0.460759 & 0.6457 \\
\hline PROFIT*FCF & -0.000594 & 0.001677 & -0.354098 & 0.7238 \\
\hline PROFIT*LEV & -0.000362 & 0.001552 & -0.233379 & 0.8158 \\
\hline PROFIT & 0.000866 & 0.002890 & 0.299528 & 0.7650 \\
\hline $\mathrm{FCF}^{\wedge} 2$ & 0.022273 & 0.046068 & 0.483485 & 0.6295 \\
\hline FCF*LEV & 0.011155 & 0.072898 & 0.153019 & 0.8786 \\
\hline FCF & 0.066541 & 0.080121 & 0.830509 & 0.4077 \\
\hline $\mathrm{LEV}^{\wedge} 2$ & -0.006289 & 0.070769 & -0.088872 & 0.9293 \\
\hline LEV & 0.073922 & 0.257454 & 0.287126 & 0.7744 \\
\hline R-squared & 0.013410 & Mean c & ndent var & 0.058817 \\
\hline $\begin{array}{l}\text { Adjusted } \\
\text { R-squared }\end{array}$ & -0.050014 & S.D. de & dent var & 0.254193 \\
\hline $\begin{array}{l}\text { S.E. of } \\
\text { regression }\end{array}$ & 0.260472 & Akaike & criterion & 0.211698 \\
\hline $\begin{array}{l}\text { Sum squared } \\
\text { resid }\end{array}$ & 9.498395 & Schwa & riterion & 0.412407 \\
\hline Log likelihood & -5.877342 & Hannan & nn criter. & 0.293240 \\
\hline F-statistic & 0.211429 & Durbin & son stat & 2.049191 \\
\hline $\begin{array}{l}\text { Prob(F- } \\
\text { statistic) }\end{array}$ & 0.992426 & & & \\
\hline
\end{tabular}


Dalam uji white, hipotesis yang diajukan adalah:

$\mathrm{H}_{\mathrm{o}}$ : Tidak ada heterokedastisitas

$\mathrm{H}_{\mathrm{a}}$ : Ada Heterokedastisitas

Berdasarkan tabel di atas, dapat dilihat nilai $\mathrm{Obs}^{\star} \mathrm{R}$-squared mempunyai nilai probabilitas Chi-square sebesar $\mathrm{p}=0,99130$ yang mana $\mathrm{p}$-value tersebut lebih dari (>) 0.05, Dengan demikian maka hipotesis tidak teradi maslah heterokedastisitas.

c. Uji Multikolinearitas

\begin{tabular}{|c|c|c|c|}
\hline \multicolumn{4}{|c|}{ Tabel 7. Uji Multikolinearitas } \\
\hline \multicolumn{4}{|c|}{$\begin{array}{l}\text { Variance Inflation Factors } \\
\text { Date: 10/13/18 Time: 22:39 } \\
\text { Sample: } 1150 \\
\text { Included observations: } 150\end{array}$} \\
\hline Variable & $\begin{array}{c}\text { Coefficient } \\
\text { Variance }\end{array}$ & $\begin{array}{c}\text { Uncentered } \\
\text { VIF }\end{array}$ & $\begin{array}{c}\text { Centered } \\
\text { VIF }\end{array}$ \\
\hline c & 0.004576 & 11.35866 & NA \\
\hline PROFIT & $1.66 \mathrm{E}-07$ & 1.498242 & 1.014885 \\
\hline FCF & 0.001788 & 2.923891 & 1.406451 \\
\hline LEV & 0.002159 & 6.684273 & 1.406001 \\
\hline
\end{tabular}

Berdasarkan tabel di atas dapat dilihat bahwa nilai Centered VIF untuk variabel Profit, FCF dan LEV seluruhnya dibawah 10 dan diatas 0,10 yatitu $1.014885,1.406451,1.406001$ maka dapat diartikan bahwa tidak terdapat multikolonieritas pada penelitian ini.

d. Uji Autokorelasi

Uji ini bermaksud untuk mengetahui apakah ada korelasi antara anggota serangkaian data observasi yang diuraikan menurut waktu (time series) dan ruang (cross section). Uji Autokorelasi dalam penelitian ini dilakukan dengan metode Durbin-Waston (DW).

\begin{tabular}{|c|c|c|c|c|}
\hline \multicolumn{5}{|c|}{ Tabel 8. Uji Autokorelasi } \\
\hline \multicolumn{5}{|c|}{$\begin{array}{l}\text { Correlated Random Effects - Hausman Test } \\
\text { Equation: Untitled } \\
\text { Test cross-section random effects }\end{array}$} \\
\hline \multicolumn{2}{|c|}{ Test Summary } & $\begin{array}{l}\text { Chi-Sq. } \\
\text { Statistic }\end{array}$ & Chi-Sq. d.f. & Prob. \\
\hline \multicolumn{2}{|c|}{ Cross-section random } & 0.673045 & 3 & 0.8795 \\
\hline \multicolumn{5}{|c|}{ Cross-section random effects test comparisons: } \\
\hline Variable & Fixed & Random & Var(Diff.) & Prob. \\
\hline PROFIT & -0.000074 & -0.000132 & 0.000000 & 0.7026 \\
\hline FCF & 0.055766 & 0.043510 & 0.000571 & 0.6081 \\
\hline LEV & 0.148893 & 0.158919 & 0.000311 & 0.5694 \\
\hline
\end{tabular}

\begin{tabular}{|c|c|c|c|c|}
\hline \multicolumn{5}{|c|}{$\begin{array}{l}\text { Cross-section random effects test equation: } \\
\text { Dependent Variable: MAN_LABA } \\
\text { Method: Panel Least Squares } \\
\text { Date: } 10 / 13 / 18 \text { Time: } 22: 25 \\
\text { Sample: } 20122017 \\
\text { Periods included: } 6 \\
\text { Cross-sections included: } 25 \\
\text { Total panel (balanced) observations: } 150\end{array}$} \\
\hline Variable & Coefficient & Std. Error & t-Statistic & Prob. \\
\hline C & 0.206287 & 0.060528 & 3.408142 & 0.0009 \\
\hline PROFIT & $-7.41 \mathrm{E}-05$ & 0.000426 & -0.173976 & 0.8622 \\
\hline FCF & 0.055766 & 0.049377 & 1.129382 & 0.2610 \\
\hline LEV & 0.148893 & 0.046827 & 3.179635 & 0.0019 \\
\hline \multicolumn{5}{|c|}{ Effects Specification } \\
\hline \multicolumn{5}{|c|}{ Cross-section fixed (dummy variables) } \\
\hline R-squared & & 0.523239 & $\begin{array}{l}\text { Mean } \\
\text { dependent } \\
\text { var }\end{array}$ & 0.384100 \\
\hline \multicolumn{2}{|c|}{ Adjusted R-squared } & 0.417727 & $\begin{array}{l}\text { S.D. } \\
\text { dependent } \\
\text { var }\end{array}$ & 0.257044 \\
\hline \multicolumn{2}{|c|}{ S.E. of regression } & 0.196142 & $\begin{array}{l}\text { Akaike info } \\
\text { criterion }\end{array}$ & -0.253238 \\
\hline \multicolumn{2}{|c|}{ Sum squared resid } & 4.693539 & $\begin{array}{l}\text { Schwarz } \\
\text { criterion }\end{array}$ & 0.308747 \\
\hline \multicolumn{2}{|c|}{ Log likelihood } & 46.99286 & $\begin{array}{l}\text { Hannan- } \\
\text { Quinn criter. }\end{array}$ & -0.024921 \\
\hline \multicolumn{2}{|l|}{ F-statistic } & 4.959024 & $\begin{array}{l}\text { Durbin- } \\
\text { Watson stat }\end{array}$ & 1.522981 \\
\hline \multicolumn{2}{|c|}{ Prob(F-statistic) } & 0.000000 & & \\
\hline
\end{tabular}

Dari tabel di atas Uji Autokorelasi dalam penelitian ini dilakukan dengan metode Durbin-Waston (DW). Dapat dilihat bahwa Nilai Durbin Waston stat 1.522981 dan Nilai DU diperoleh 1.77406. Karena nilai DW $<$ DU $(1.522981$ $>1.77406)$, Maka dapat disimpulkan terjadi autokorelasi pada data tersebut.

\section{Pengujian Hipotesis}

\begin{tabular}{|c|c|c|c|c|}
\hline \multicolumn{5}{|c|}{ Tabel 9. Hasil Analisis Regresi Berganda } \\
\hline \multicolumn{5}{|c|}{$\begin{array}{l}\text { Hasil Analisis Regresi Berganda Model Random Effect } \\
\text { Dependent Variable: MAN_LABA } \\
\text { Method: Panel EGLS (Cross-section random effects) } \\
\text { Date: } 10 / 13 / 18 \text { Time: } 22: 24 \\
\text { Sample: } 20122017 \\
\text { Periods included: } 6 \\
\text { Cross-sections included: } 25 \\
\text { Total panel (balanced) observations: } 150 \\
\text { Swamy and Arora estimator of component variances }\end{array}$} \\
\hline Variable & Coefficient & Std. Error & t-Statistic & Prob. \\
\hline C & 0.205503 & 0.067155 & 3.060156 & 0.0026 \\
\hline PROFIT & -0.000132 & 0.000398 & -0.333124 & 0.7395 \\
\hline FCF & 0.043510 & 0.043208 & 1.007008 & 0.3156 \\
\hline LEV & 0.158919 & 0.043385 & 3.663036 & 0.0003 \\
\hline \multicolumn{5}{|c|}{ Effects Specification } \\
\hline & & & S.D. & Rho \\
\hline \multicolumn{3}{|c|}{ Cross-section random } & 0.160615 & 0.4014 \\
\hline \multicolumn{3}{|c|}{ Idiosyncratic random } & 0.196142 & 0.5986 \\
\hline
\end{tabular}




\begin{tabular}{|l|c|l|c|}
\hline \multicolumn{4}{|c|}{ Weighted Statistics } \\
\hline R-squared & 0.087093 & $\begin{array}{l}\text { Mean } \\
\text { dependent } \\
\text { var }\end{array}$ & 0.171376 \\
\hline Adjusted R-squared & 0.068335 & $\begin{array}{l}\text { S.D. } \\
\text { dependent } \\
\text { var }\end{array}$ & 0.201582 \\
\hline S.E. of regression & 0.194573 & $\begin{array}{l}\text { Sum } \\
\text { squared } \\
\text { resid }\end{array}$ & 5.527336 \\
\hline F-statistic & 4.642881 & $\begin{array}{l}\text { Durbin- } \\
\text { Watson stat }\end{array}$ & 1.304008 \\
\hline Prob(F-statis tic) & 0.003940 & -0.024921 \\
\hline \multicolumn{4}{|c|}{ Unweighted Statistics } \\
\hline R-squared & 0.100272 & $\begin{array}{l}\text { Mean } \\
\text { dependent } \\
\text { var }\end{array}$ & 0.384100 \\
\hline Sum squared resid & 8.857499 & $\begin{array}{l}\text { Durbin- } \\
\text { Watson stat }\end{array}$ & 0.813739 \\
\hline \multicolumn{4}{|c|}{ Sumber: Diolah penulis menggunakan e-views } \\
\hline
\end{tabular}

a. Uji Signifikasi ANOVA (F test)

Berdasarkan tabel output 4.12, diperoleh nilai $\mathrm{F}$ Statistic $>\mathrm{f}_{\text {tabel }}$ $(4.642881>2.43)$ dan signifikasi 0.05 probabilitas sebesar 0.000000 . Oleh karena probabilitas jauh lebih kecil dari 0.05, maka dapat disimpulkan bahwa koefisien regresi rasio profitabilitas, free cash flow dan leverage dengan kata lain $\mathrm{H}_{1}$ diterima dan menolak $\mathrm{H}_{0}$. Kesimpulan hasil outputnya adalah ketiga variabel independen secara bersamasama berpengaruh positif terhadap manajemen laba.

b. Uji signifikansi parsial (uji t test)

1) Hipotesis Pertama

Berdasarkan tabel 4.12 nilai signifikansi sebesar $0.7395>0.05$ dengan nilai $\mathrm{t}_{\text {hitung }}$ sebesar $-0.333124<\mathrm{t}_{\text {tabel }}$ sebesar 2.43 berdasarkan hasil diatas maka $\mathrm{H}_{1}$ ditolak dan $\mathrm{H}_{0}$ diterima, yang berarti rasio profitabilitas independen tidak berpengaruh terhadap manejemen secara parsial.

2) Hipotesis Kedua

Berdasarkan tabel 4.12 nilai signifikansi sebesar $0.3156>0.05$ dengan nilai $\mathrm{t}_{\text {hitung }}$ sebesar 1.007008 $<\mathrm{t}_{\text {tabel }}$ sebesar 2.43, berdasarkan hasil diatas maka $\mathrm{H}_{0}$ diterima dan $\mathrm{H}_{1}$ ditolak, yang berarti free cash flow tidak berpengaruh terhadap manajemen laba secara parsial.

3) Hipotesis Ketiga

Berdasarkan tabel 4.12 nilai signifikansi sebesar $0.0003<0.05$ dengan nilai $\mathrm{t}_{\text {hitung }}$ sebesar 3.663036 $>\mathrm{t}_{\text {tabel }}$ sebesar 2.43, berdasarkan hasil diatas maka $\mathrm{H}_{0}$ ditolak dan $\mathrm{H}_{1}$ diterima, yang berarti Leverage berpengaruh terhadap manjemen laba.

c. Analisis berganda

Berdasarkan tabel 4.12 diatas hasil analisis regresi berganda menunjukkan bahwa nilai probabilitas kualitas Rasio profitabilitas $0.7395>0.05$, hal ini berarti varibel Rasio profitabilitas tidak berpengaruh terhadap manajemen laba, nilai probabilitas free cash flow $0.3156>$ 0.05 hal ini berarti variabel free cash flow tidak berpengaruh terhadap manajemen laba, nilai probablitas Leverage 0.0003 $<0.05$ hal ini berarti menunjukkan variabel Leverage berpengaruh terhadap manajemen laba.

Persamaan regresi yang dihasilkan pada tabel 4.12 adalah sebagai berikut: Man_Lab $=0.205503-0.000132$ PROFIT $+0.043510 \mathrm{FCF}+0.158919 \mathrm{LEV}$.

d. Korelasi (Uji r)

"Koefisien korelasi (r) digunakan untuk mengetahui kuat atau lemahnya hubungan antara variabel independen secara keseluruhan terhadap variabel dependen. Semakin besar nilai $r$ (mendekat angka 1) maka semakin kuat hubungan antara variabel independen dan dependennya. Koefisien korelasi (R-squared) pada tabel 4.12 menunjukkan angka 0.100272. Angka ini menjelaskan bahwa hubungan pengaruh variabel rasio profitabilitas, free cash flow dan Leverage terhadap manajemen laba adalah lemah.

e. Uji Koefisien Determinasi $\left(\mathrm{R}^{2}\right)$

Tampilan output pada tabel 4.12 menunjukkan besarnya adjusted $\mathrm{R}^{2}$ sebesar 0.100272 , hal ini berarti hanya $10.0272 \%$ variasi manajemen laba dapat 
dijelaskan oleh variasi dari tiga variabel independen variabel sedangkan sisa rasio profitabilitas, Free Cash Flow dan Leverage sedangkan sisanya $89.9728 \%$ dijelaskan oleh sebab-sebab lain diluar model dalam penelitin ini.

\section{Pembahasan Hasil Pengujian}

\section{Rasio Profitabilitas}

\section{Terhadap Manajemen Laba}

Berdasarkan hasil penelitian yang tertera pada tabel output 4.12 ditemukan propsi profitabilitas tidak berpengaruh terhadap manajemen laba. Dengan nilai signifikansi sebesar $0.7395>0.05$ dengan nilai $\mathrm{t}_{\text {hitung }}$ sebesar $-0.333124<\mathrm{t}_{\text {tabel }}$ sebesar 1.65754 berdasarkan hasil diatas maka $\mathrm{H}_{1}$ ditolak dan $\mathrm{H}_{0}$ diterima, yang berarti rasio profitabilitas independen tidak berpengaruh terhadap manajemen secara parsial.

Dapat disimpulkan bahwa semakin tinggi atau rendahnya profitabilitas yang diperoleh tidak berpengaruh terhadap manajemen laba. Hal ini disebabkan karena kejadian profitabilitas setelah terjadinya manajemen laba, sehingga tidak berpengaruh dengan manajemen laba nilai profit didapatkan dari pengurangan setelah pajak dan bunga baru ditemui profitabilitas, dan jika semakin tinggi profitabilitas, deviden yang dibagikan semakin besar. Profitabilitas yang semakin meningkat menunjukkan kinerja perusahaan yang baik dan para pemegang saham akan menerima keuntungan yang semakin meningkat. Karena manajer juga mendapatkan keuntungan sehingga dia tidak melakukan tindakan manajemen laba.

Penelitian ini mendukung hasil penelitian yang dilakukan oleh Muhammad Ar Irsayd (2008) dan Prasetya dan Rahardjo (2013) yang menyatakan profitabiltas tidak berpengaruh terhadap manajemen laba.

Dan hasil penelitian ini tidak sejalan dengan hasil penelitian dari Guna dan Herawaty (2010), Amerta (2013), Bok et al. (2011), Hamza dan Lakhal (2010), Shimin et al. (2009), Widyastuti (2009), dalam hasil penelitiannya Rasio Profitabilitas memiliki pengaruh terhadap Manajemen Laba.

Pada tabel ouput hasil penelitian ini tidak sejalan dengan hasil penelitian dari Guna dan Herawaty (2010), Amerta (2013), Bok et al. (2011), Hamza dan Lakhal (2010), Shimin et al. (2009), Widyastuti (2009), dalam hasil penelitiannya Rasio Profitabilitas memiliki pengaruh terhadap Manajemen Laba.

\section{Pengaruh Free Cash Flow} Terhadap Manajemen Laba

Berdasarkan hasil pengolahan data pada tabel 4.12, variabel ditemukan bahwa $\mathrm{H}_{1}$ ditolak artinya, Free Cash Flow tidak berpengaruh terhadap manajemen laba. Hal ini terbukti dari nilai probablilitas nilai $0.3156>$ 0.05 dengan nilai $\mathrm{t}_{\text {hitung }} 1.007008<\mathrm{t}_{\text {tabel }}$ sebesar 2.43. Dari Hasil penelitian ini membuktikan bahwa hipotesis yang menyatakan free cash flow berpengaruh terhadap manajemen laba tidak terbukti. Berdasakan hasil analisis tersebut dapat disimpulkan bahwa free cash flow yang tinggi akan membatasi praktik manajemen laba, karena dalam hal ini sebagian besar investor merupakan pemilik sementara perusahaan yang lebih terfokus pada informasi arus kas bebas perusahaan yang menunjukkan bagaimana kemampuan perusahaan dalam membagikan deviden, sehingga dengan arus kas yang tinggi tanpa adanya manajemen laba perusahaan sudah bisa meningkatkan harga sahamnya karena investor melihat bahwa perusahaan tersebut mempunyai kelebihan kas untuk pembagian deviden.

3. Pengaruh Leverage Terhadap Manajemen Laba

Berdasarkan tabel 4.12, variabel Leverage menunjukkan nilai probabilitas sebesar $0.0003<$ nilai signifikan 0.05 dengan nilai $\mathrm{t}_{\text {hitung }} 3.66036>\mathrm{t}_{\text {tabel }} 2.43$ Sehingga hipotesis ke-3 didukung atau $\mathrm{H}_{0}$ ditolak. Hal ini menunjukkan bahwa Leverage pengaruh terhadap terdeteksinya Manajemen Laba. Sehingga, Leverage atau perusahaan dapat dijadikan acuan untuk mendeteksi terjadinya Manajemen Laba. Hal ini disebabkan karena perusahaan manufaktur yang di- 
jadikan sampel tergantung pada utang dalam membiayai aset perusahaan, sehingga mempengaruhi terhadap keputusan manajemen perusahaan, leverage juga dapat memicu praktik manajemen laba dikarenakan kepentingan perusahaan untuk memperoleh modal dari kreditur dan perhatian investor.

Hasil penelitian ini sesuai dengan teori keagenan yang dikemukakan Jansen dan Meckling (1976) bahwa terdapat hubungan keagenan antara manajer dan kreditur (debt to equity hypothesis) dimana perusahaan yang mempunyai rasio leverage yang tinggi maka manajer perusahaan tersebut cenderung menggunakan metode akutansi yang akan meningkatkan laba agar kinerja perusahaan terlihat baikdengan harapan kreditur dapat mempercayai kinerja perusahaan tersebut. Sehingga informasi tersebut dapat meyakinkan kreditur yang beranggapan bahwa debitur dapat membeyarkan hutangnya kepada (principal) kreditur.

Hasil penelitian ini tidak sejalan dengan hasil penelitian dari Husna dan Zulfikar (2016), dan Mohamad et al. yang menyatakan Leverage tidak berpengaruh terhadap manajemen laba.

\section{SIMPULAN}

Tujuan pertama dari penelitian ini adalah untuk memberikan bukti empiris dan menganalisis pengaruh profitabilitas terhadap manajemen laba. Dengan hipotesis pertama menyebutkan bahwa profitabilitas berpengaruh signifikan terhadap manajemen laba. Berdasarkan hasil analisis data dan pembahasan yang telah dikemukakan, diperoleh hasil yang menyebutkan bahwa profitabilitas tidak berpengaruh signifikan terhadap manajemen laba. Sehingga tujuan pertama dalam penelitian ini telah tercapai dan hipotesis pertama dalam penelitian ini ditolak.

Tujuan kedua dari penelitian ini adalah untuk memberikan bukti empiris dan menganalisis pengaruh free cash flow terhadap manajemen laba. Dengan hipotesis kedua menyebutkan bahwa free cash flow berpengaruh positif signifikan terhadap manajemen laba. Berdasarkan hasil analisis data dan pembahasan yang telah dikemukakan, diperoleh hasil yang menyebutkan bahwa free cash flow tidak berpengaruh signifikan terhadap manajemen laba. Sehingga tujuan kedua dalam penelitian ini telah tercapai dan hipotesis kedua dalam penelitian ini diterima.

Tujuan ketiga dari penelitian ini adalah untuk memberikan bukti empiris dan menganalisis pengaruh Leverage terhadap manajemen laba. Dengan hipotesis ketiga menyebutkan bahwa Leverage berpengaruh positif signifikan terhadap manajemen laba. Berdasarkan hasil analisis data dan pembahasan yang telah dikemukakan, diperoleh hasil yang menyebutkan bahwa Leverage berpengaruh signifikan terhadap manajemen laba. Sehingga tujuan ketiga dalam penelitian ini telah tercapai dan hipotesis ketiga dalam penelitian ini diterima.

Tujuan keempat dari penelitian ini adalah untuk memberikan bukti empiris dan menganalisis pengaruh profitabilitas, free cash flow dan leverage secara bersama-sama terhadap manajemen laba. Dengan hipotesis keempat menyebutkan bahwa profitabilitas, free cash flow dan leverage secara bersama-sama berpengaruh signifikan secara bersama-sama terhadap manajemen laba.

\section{PENGHARGAAN}

Terima kasih yang sebesar-besarnya kepada berbagai pihak yang telah memberikan dukungan kepada penulis dalam penyelesaian penelitian ini, terutama kepada:

1. Bapak DR. (HC) Darsono selaku Ketua Yayasan Sasmita Jaya yang telah memberikan dukungan moril dan materiil kepada penulis sehingga dapat terselesaikan tepat waktu.

2. Bapak DR. H. Endang Ruhiyat,. S.E., M.M., CSRA., CMA Selaku Dekan Akuntansi Universitas Pamulang.

3. Ibu Effriyanti, S.E., M.M., Akt., M.Si., CA., Selaku Ketua Program Studi Akuntansi Universitas Pamulang.

4. Bapak Dr. Hendry., MM selaku dosen Selaku Pembimbing 1 dalam penelitian ini.

5. Bapak Prof. Dr. Adji Suratman, CA, CPMA, 
CPA, Ak. Selaku Pembimbing 2 dalam penelitian ini

6. Keluarga tercinta yang selalu mendukung, memotivasi dan memberikan perhatiannya dengan tanpa pamrih.

7. Rekan-rekan ikadin Y.A.I yang selalu meningatkan dan memberi dukungan satu sama lain.

8. Semua Pihak yang telah membantu dan mendukung penulis dalam menyelesaikan penelitian ini yang tidak dapat disebutkan satu persatu.

\section{DAFTAR PUSTAKA}

Agustia, D. (2013). Pengaruh Faktor Good Corporate Governance, Free Cash flow, dan Leverage Terhadap Manajemen Laba. Jurnal Akuntansi dan Keuangan 15(1): 27-42.

Azlina, N. (2010). Analisis Faktor yang Mempengaruhi Manajemen Laba. Pekbis Jurnal. Vol.2, No.3, November 2010: 355-363.

Belkaoui, A. R. (2004). Accounting Theory. Jakarta: Salemba Empat.

Brigham, E. F, and Houston, J. F. (2008). Manajemen Keuangan Edisi Delapan, Buku 1. Jakarta: Salemba Empat.

Brigham, E. F, and Houston, J. F. (2010). Dasardasar Manajemen Keuangan (Essential of Financial Management). Edisi ke sebelas, buku 1. Terjemahan oleh Ali Akbar Yulianto. Jakarta: Salemba Empat.

Bukit, R. B. and Iskandar, T. M. (2009). Surplus Free Cash Flow, Earnings Management and Audit Committee. Int. Journal of Economics and Management, 3(1), 204-223.

Chariri, A., dan Ghozali, I. (2007). Teori Akuntansi. Semarang: Badan Penerbit Universitas Diponegoro.

Damayanthi, L. M. (2016). Pengaruh Arus Kas Bebas, Capital Adequacy Ratio dan Good Corporate Governance Pada Manajemen Laba. E-Jurnal Akuntansi Universitas Udayana, 1056-1085.

DeAngelo, H., DeAngelo, L., and Skinner. D. (1994). Accounting choice in troubled companies. Journal of Accounting and
Economic, 17 113-143.

Dechow, Patricia, Richard G. Sloan, Amy P. Sweeney. (1995). "Detecting Earning Management. The Accounting Review, Vol.70, No.2 PP. 193-225.'

Ghozali, I. dan Chariri, A. (2007). Teori Akuntansi. Semarang: Badan Penerbit Universitas Diponegoro.

Gunawan, I. K., Darmawan, N. A. S, \& Purnamawati, I. G. A. (2015). Pengaruh Ukuran Perusahaan, Profitabilitas, dan Leverage terhadap Manajemen Laba pada Perusahaan Manufaktur yang Terdaftar di Bursa Efek Indonesia BEI). E-journal S1 Ak Universitas Pendidikan Ganesha Jurusan Akuntansi Program S1 03(01): 1-10.

Hafidza, A. U. (2017). Pengaruh Leverage Terhadap Manajemen Laba dengan Corporate Governance Sebagai Variabel Moderasi pada Perusahaan Perbankan Yang Terdaftar di BEI.

Handayani, Rr. S., Dan Rachadi, A. D. (2009) Pengaruh Ukuran Perusahaan Terhadap Manajemen Laba. Jurnal Akuntansi dan Keuangan, Vol.11, No. 1 Halaman 35-56.

Hery. (2015). Analisis Laporan Keuangan. (T. Atmojo, Penerj.) Yogyakarta: CAPS.

Jao, R., dan Pagulung, G. (2011). "Corporate Governance, Ukuran perusahaan dan Leverage terhadap Manajemen Laba Perusahaan Manufaktur Indonesia”. Jurnal Akuntasi \& Auditing Volume 8/No.1.

Kamaliah, et all. (2014). Aktivitas manajemen laba: Analisis Peran Komite Audit, Kepemilikan Institusional, Persentasi Saham Publik dan Leverage. Simposium Nasional Akuntansi XVII. Mataram, Lombok.

Kusumawardhani, I. (2012). Pengaruh Corporate Governance, Struktur Kepemilikan dan Ukuran Perusahaan Terhadap Manajemen Laba.

Lande, A., Subekti, I., dan Mardiati, E. (2014). Pengaruh Tata Kelola Perusahaan, Kecakapan Manajerial, dan Rasio Leverage terhadap Manajemen Laba. Simposium Nasional Akuntansi XVII. Mataram, Lombok.

Muhidin, et.al. (2007). Analisis Korelasi, Regresi, dan Jalur Dalam Peneitian. Bandung: Pustaka Setia. 
Pambudi, J. E. dan Sumantri, F. A. (2014). Kualitas Audit, Ukuran Perusahaan dan Leverage terhadap Manajemen Laba. Simposium Nasional Akuntansi XVII. Mataram, Lombok. Puji, A. D. S. (2004). Analisis Faktor-Faktor Yang Mempengaruhi Motivasi Manajemen Laba di Seputar Right Issue. Jurnal Akuntansi. Universitas Slamet Riyadi.

Sarana Indonesia. Jakarta. Jurnal Ilmu dan Riset Akuntansi: Volume 5, Nomor 2, ISSN: 24600585.

Sawir, A. (2009). Analisa Kinerja Keuangan dan Perusahaan. Jakarta: PT Gramedia Pustaka Utama, Jakarta.

Scott, W. R. (2006). Financial Accounting Theory. Edisi Keempat. US: Prentice Hall.

Sugiyono.(2012).Metodelogi Penelitian Kuantitatif Kulitatif dan R\&D. Bandung: Alfbeta.

Sugiyono, A. \& Untung, E. (2008). Panduan
Praktis Dasar Analisa Laporan Keuangan. Sulistyanto, S. (2008). Manajemen Laba: Teori dan Model Empiris. Jakarta: PT. Grasindo.

Syafri, H. S. (2008). Analisa Kritis atas Laporan Keuangan. Jakarta: PT. Raja Grafindo Persada.

Syamsuddin, L. (2001). Manajemen Keuangan Perusahaan. Jakarta: PT. Raja Grafindo Persada.

Tampubolon, M. (2005). Manajemen Keuangan. Edisi Pertama. Jakarta: Ghalia Indonesia.

Welvin, I. G., dan Arleen, H. (2010). Pengaruh Mekanisme Good Corporate Governance, Indenpendensi auditor, Kualitas Audit Dan Faktor Lainnya terhadap Manajemen Laba. Jurnal Akuntasi Vol.12 No 1 Hal 52-68.

Winarno, W. W. (2009). Analisis Ekonometrika dan Statistik dengan Eviews. Edisi kedua. Yogyakarta: UPP STIM YKPN. 